\title{
Innovation as a Source of Competitive Advantage in Human Resource Management: Case of Travel Agencies in the UAE
}

\author{
Dr. Almaz Sandybayev" (ADMC), Dr. Roudaina Houjeir (ADMC) \\ Assistant Prof., Higher Colleges of Technology, Abu Dhabi Men's College, Faculty of Business, United Arab \\ Emirates
}

*Corresponding Author: Dr. Almaz Sandybayev, Assistant Prof., Higher Colleges of Technology, Abu Dhabi Men's College, Faculty of Business, United Arab Emirates

\begin{abstract}
This research presents an overview of issues related to the role of human resources in creating innovation in tourism enterprises in the United Arab Emirates. Abu Dhabi's leading travel companies and agencies in tourism been selected to identify the increasing role of SHRM and most importantly innovative activities in the researched entities. Following previous years, February 2018 has been announced as a month of innovations, where innovation was getting a widespread meaning and a tool of creativity and design thinking in all organizations and companies across the UAE.

Thus, the research tries to validate the main hypothesis that SHRM practices positively relate to innovation and knowledge performance factors. The article aims to understand the indicated factors as main drivers of innovation and its impact on human resources. The proposed model theorizes a significant correlation between variables that remains between SHRM processes and companies overall 'innovation factor' performance in tourism sector. Further, it is becoming essential to reconsider the management approach in tourism field to discover new methods attributed to employees in finding innovative and creative solutions.
\end{abstract}

Keywords: Innovation, SHRM, Knowledge management, Abu Dhabi

\section{INTRODUCTION}

Since its start in 1971, the United Arab Emirates (UAE) has continually been distinguished as a portrait for innovation. It is deliberated the fastest growing market in the region and is categorized as the most innovation-driven economy in the Arab world (EW 2010; DCCI 2010; WEF 2010). The country's leadership aims to create a knowledge-based economy powered by innovation. The UAE is rapidly transforming from an oil-based economy to an innovative, knowledge-based economy. By moving towards a knowledge-based economy, the UAE has diversified its economy and positioned itself as a key player in real estate, renewable energy and aviation; it has also become a global pivot for trade and logistics, financial services and tourism. The UAE today is considered as one of the most popular tourist destinations.

In the current competitive globalized marketplace when knowledge is speedily changing, innovation has become almost a precondition for business success (Hamel, 2008; Jamrog, Vickers and Bear, 2006) and the human capital of the organization is a concern of increasing significance. Innovation is an imperative subject of research in tourism. Innovation denotes a potential new solution to problems in tourism services and issues which comprise a change of actual state and has a significant part to play in the development of some fields of the tourism economy. Bestowing to the authors, human resources are vital in attaining product innovation, particularly in the tourism sector. A high level of rigorous interaction between employees and clients is advantageous to the implementation of the innovative ideas created in this type of interaction.

Strategic Human Resource Management (SHRM) has a critical function in inspiring innovation processes in companies ( $\mathrm{Li}$, Zhao and Liu, 2006), by affecting creativity (Jiang et al., 2012) and knowledge sharing (Jiménez-Jiménez and Sanz-Valle, 2011). So SHRM practices become vital to how organizations effect and shape attitude, behavior and skills of individuals, of prominence to whether organizations deliver innovations that relates to their goals (Chen and Huang, 2009). Innovation initiatives tend to depend greatly on employees' knowledge, skills, and commitment as important components in the value creation process (Youndt, Snell, Dean and Lepak, 1996). 
For innovation to take place, firms need to manage human capital that has the capability to turn knowledge into practical products and services. Knowledge is controlled by human capital and cannot simply be transferred inside the firm (Hansen, 1999; Grant, 1996). Though a firm has access to the knowledge, skills and expertise of employees, it also needs knowledge management tools in place to confirm active use of human capital. Knowledge management is an approach to adding value by more vigorously leveraging the know-how and experience exists in in individual minds (Ruggles, 1998; Scarbrough, 2003). Knowledge management may affect the relationship between HR practices and innovation performance. Hence, in this study we tried to examine whether SHRM practices will affect innovation performance through the intermediate variable of knowledge management.

\section{LITERATURE REVIEW}

This section will discuss the role of Strategic Human Resources Management in creating innovation in tourism enterprises in the UAE. The definition of innovation capability, strategic human resource management and knowledge management in the tourism sector will be deliberated.

\subsection{Tourism}

The variety of tourism innovation definitions can be attributed to the different drives authors have used for examining this phenomenon. Novelty is one of the main explanations of innovation when studied in tourism (KvamandStrate 2010). Throughout history, tourism has been a phenomenon categorized by massive innovativeness. Tourism is deliberated as an activity that is vital to the life of nations (Anonymous, 1995). Tourism is a very important contributor to the nation's wealth (Mangion and Vella, 2000). Tourism is a social phenomenon of modern society (Urry, 2000) that assumes to improve people's lives (Furchtgott and Furchtgott, 1999). Tourism is an economic, important and diverse phenomenon that affects both the travelers and the population of tourist facilities. Tourism plays a substantial and essential role in the United Arab Emirates with 2 million tourists coming every year (Sandybayev, et al. 2018). They bring substantial financial profits to the economy and contribute to the social economic growth of the region and the country itself.

In current years, the United Arab Emirates has experienced rapid economic growth, impressive by any global standards. According to the World Travel \& Tourism Council (WTTC), tourism contributed US\$64 billion to the UAE's economy in 2016. The UAE is strongminded to become one of the world's leading tourism destinations and WTTC's report reveals that in 2015, it was ranked 28th out of 184 countries in terms of the relative significance of travel and tourism's total contribution to GDP. Looking at the 10-year growth forecast, WTTC says the UAE ranks in 48th place. By 2026, the number of international tourists visiting the UAE will increase by 30.94 million with spending over $\$ 45.66$ billion based on WTTC data. Thus, travelling to UAE is becoming more prevalent by the international tourists (Sandybayev, et al. 2018).

\subsection{Innovation}

Competition amongst firms is getting tougher due to globalization, deregulation, the dynamics of user needs and new technologies. In order to persist and improve growth, firms must continuously create innovation. Innovation is defined as an economically and socially successful introduction of a new way or a new combination of existing ways in transforming inputs into outputs that results in changes in the value/price relationship offered to the users (De Meyer and Garg, 2005; Fontana, 2011). Innovation is very important to achieve successful performance results in the companies. The increasing economic prominence of innovation is stressed in the literature and in economic and social practice. Innovation is the process by which a supposed opportunity becomes a new idea and then finds prevalent practical application (Tidd and Bessant 2013, 19).

Innovation is commonly deliberated to be introducing or improving products, practices, defining or redefining market positioning (Tidd, Bessant and Pavitt, 2005). In attaining innovation, the contribution of the human factors within the organization are critical. Where innovation happens, the capabilities of the organization and individuals within it need to be harnessed efficiently in order to implement change. Organizations should develop innovation capability to manage innovation process from generating ideas to commercialization. Strategic human resource management (SHRM) is deliberated as a key element to innovation capability since the human element is involved in the innovation process. Hence, organizations need to innovate in order to persist and grow and also outrival as well as considerably influencing industry direction (Davila et al, 2006; Trott 2008; Crossan and Apaydin, 2010). 
Skarzynski and Gibson (2008) clarified that in order to get a good innovation performance, the company needs to have the capability of innovation. The same opinion was also provided by Davila et al (2006) which identified the need for organizations to develop innovation capabilities based on the positive behavior, competence and motivation of the supervisory ranks and employees to get a good innovation. Lawson and Samson (2001) described the innovation capability as the capability of the organization to transmute knowledge and ideas into new products, new processes for the advantage of the organization and its stakeholders. However; Madanmohan (2003) states innovation capability as the organization's capability to reconfigure and improve their resources and organizational capabilities to innovate.

\subsection{Strategic Human Resource Management (SHRM)}

Strategic Human Resource Management (SHRM) has urbanized as a field of management practice and an area of research since the middle of 1980's. SHRM can be defined as "the pattern of planned human resource deployments and activities intended to enable the firm to achieve its goals" (Wright and McMahan, 1992, p.298). Gomez-Mejía et al (2007) and Snell and Bohlander (2010) recommended in order to have competent human resources, organizations need to develop active human resources policies and activities. According to Millmore, Lewis, Saunders, Thornhill and Morrow (2007), to attain optimal results, human resource management should be led strategically. It should always be allied with the company's strategy (Snell and Bohlander, 2010; Leopold and Harris, 2009). The need for strategic human resources management is also enlightened by Lengnick-Hall, Lengnick-Hall, Andrade and Drake (2009) and Pourkiani, Salajeghe and Ranjbar (2011). Furthermore, strategic human resources management is anticipated to increase innovation (Wang and Zang, 2005; Chen and Huang, 2009; Pourkiani, et al, 2011).

Human Resource Management (HRM) may be defined broadly in terms of all management activities affecting relationships between organization and employee (Beer et al., 1984) or more precisely as a system of operational functions such as staffing, selection, job design, training and career development, performance appraisal and compensation (Pfeffer, 1998). Organizations that efficiently manage and control the knowledge and experience rooted in individual minds will create more value and accomplish higher performance and competitive advantage (Ruggles, 1998; Scarbrough, 2003). Employee proficiencies can be used as a competitive advantage. Wright, Dunford and Snell (1991) added a human resources management is anticipated to be able to align the people competencies (knowledge, skills, experience, motivation, value) and the organization.

Lengnick-Hall et al (2009) and Pourkiani et al (2011) added that the strategic human resource management stresses on the company's strategic options related to human resources management and its effect on performance that are associated with firm goals. Moreover, Wright and McMahan (1992) proposed the definition of strategic human resource management as designs and activities planned for the management of human resources which are anticipated to assist the company to achieve its objectives. The interest in SHRM as a concept reveals a rising awareness that human resources are the key for success in organizations. Furthermore, Hall et al. (2009) claim that strategic human resources management is mainly about integration and adaptation. Its goal is to use efficiently human resources in respect of the strategic needs of the organization.

It is important for firms to bind the involvement and participation of employees when they develop knowledge management activities. HR practices are the main approaches used to cause and strengthen employees' skills, attitudes, and behaviors that a firm needs (Martinsons, 1995; Youndt et al., 1996; Collins and Clark, 2003). Some HR practices like staffing, trainings, participation, performance evaluation, and incentive compensation are associated to boosted commitment, lower turnover, and better performance through their effect on employee improvement and motivation. Organizations can use a set of HR practices to afford employees with the skills, resources, and discretion they need to cultivate and improve knowledge management (Huselid, 1995; Becker and Gerhart, 1996; Guthrie, 2001).

\subsection{Knowledge Management}

Knowledge management $(\mathrm{KM})$ is a growing field of research and practice attractive to both academics and professionals (Bontis and Serenko, 2009). Knowledge management is often identified as an imperative antecedent to innovation. The concept of human capital and knowledge management is that people owns skills, experience and knowledge and hence contribute to organizational innovative 
performance (Bantel and Jackson, 1989). Innovation is the result of exchanging and combining knowledge through interaction amongst numerous actors (Collins and Smith, 2006).

Chen and Huang (2009) discuss that a benefit of trainings is that it may foster employees to get new knowledge, new understandings and cultivate innovative minds and skills. As the discipline, knowledge management upholds an integrated approach to identifying, capturing, retrieving, sharing, and evaluating the firm's information assets. HRM aids the organization to articulate the drive of the knowledge management system. Organizational innovation involving the development of new products or services as well as new administrative systems is evolving as an essential source of viable competitive advantage (Damanpour, 1991). An organization's innovative capability is strictly tied to its ability to use its knowledge resources (Subramaniam and Youndt, 2005). Knowledge management is an approach of more actively leveraging the knowledge and capability to generate value and increase organizational effectiveness (Gold, Malhotra, andSegars, 2001; Ruggles, 1998; Scarbrough, 2003). A firm that displays a larger level of knowledge management activities experiences a learning effect in which it improve its capabilities in reducing redundancy, quickly retorting to change, and creating creative ideas and innovation (Scarbrough, 2003; Gold et al., 2001).

Effective knowledge management advances knowledge communication and exchange required in the innovation process, and upturns innovation performance through the development of new visions and capabilities (Madhavan and Grover, 1998; Nonaka and Takeuchi, 1995; Von Krogh, 1998). Hereafter, knowledge management plays a crucial role in supporting and fostering innovation. Attaining, developing, and employing employees with specific knowledge, skills, and abilities are critical for firms to develop knowledge management activities. Selection and recruitment of individuals with the right skills and arrogances permit firms to integrate knowledge from varied sources, and inspire innovative idea generation (Martinsons, 1995; Scarbrough, 2003). When firms use staffing systems to entice and retain competent and competent workforce, they can deal with creative thinking and problem solving to support knowledge management. Constant professional development is deliberated to be significant to knowledge workers. Firms require to offer internal and external training opportunities to cultivate and nurture required skills and capabilities of employees (Jaw and Liu, 2003; Brockbank, 1999; Nonaka and Takeuchi, 1995). Exposure to diverse education and training programs may motivate employees to learn new knowledge and expertise, increase their insight, and prepare them with innovative minds and skills (Nonaka and Takeuchi, 1995). Such knowledge and skills learning from training programs are vital for employees in the knowledge management process (Argote, McEvily and Reagans, 2003; Von Krogh, 1998), and thus stimulating active attainment of knowledge, knowledge sharing and application.

\section{RESEARCH METHODOLOGY}

\subsection{Study Group and Data Collection Tool}

The research model has been organized in a way to implement empirical research and perform survey and expert assessment methods. The survey has been conducted in Abu Dhabi, a second city after Dubai according to a number of visitors. 4.4 million Foreign tourist arrivals were recorded in 2016 which represents $8 \%$ growth compared to 2015 (TCA Abu Dhabi).It is expected to have $10 \%$ rise in hotel guests by 2018 to reach 4.9 million visitors.

The study was managed on a random sample approach representing travel agencies which been selected randomly from the Internet database. The authors sent questionnaires to 89 business entities by email. Overall, 58 useable questionnaires were returned back and analyzed, representing a response rate of $65.1 \%$ of the original research sample. Others were incomplete or had missing information which excluded them from further investigation. The identified respondents being requested to evaluate the strategic human resource management, innovation performance and knowledge management of the companies by answering specified questions. Likert-scale model with five choices has been utilized. A pilot test with 18 participants was performed to establish the validity and reliability of the questionnaire through SPSS factor analysis.

The received results were statistically described and analyzed. It is important to stress on the fact that $67.7 \%$ of the researched entities had implemented the strategy of innovation in the period of the last 2 years before the research study justifying the fact that companies have established direct policy related to innovation development and their employees are aware of this innovation performance. 
Innovation as a Source of Competitive Advantage in Human Resource Management: Case of Travel Agencies in the UAE

\subsection{The Research Hypotheses}

Three research hypotheses been developed based on literature review and research conceptual framework (Table 1).

Table1. The Research Hypotheses

\begin{tabular}{|l|l|}
\hline Hypothesis 1 & The level of SHRM practices positively relates to innovation performance. \\
\hline Hypothesis 2 & Innovation practices in a company positively relates to the knowledge management \\
\hline Hypothesis 3 & Knowledge management positively relates to the company`s SHRM practices \\
\hline
\end{tabular}

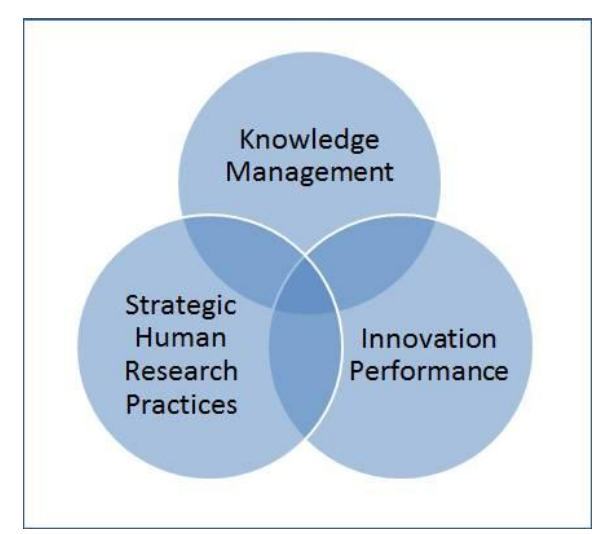

Figure1. The conceptual framework, Chen and Huang Model (2009)

Using three dimensions by Cheng and Huang (2009), the research results indicated that HR practices relate positively with knowledge management capacity which in turn is positively relates to innovation performance. Following this approach, an enhanced level of knowledge management quantity can trigger innovation and creativity that leads as a result to improved innovation performance. Consequently, our research paper proposed to test and find out positive correlations based on researched companies.

\section{RESUltS}

\subsection{Data Analysis}

The collected data has been analyzed by utilizing SPSS model. At this level, the dimension reduction approach was adopted to link the elements of each concept and suggesting one single variable. Subsequently, three interval variables been designed. Second level has been characterized as employing correlation analysis method and Pierson's method to determine the relationship between variables.

Table2. Correlation Analysis

\begin{tabular}{|l|l|l|l|l|}
\hline \multicolumn{1}{|c|}{ Variable } & \multicolumn{1}{|c|}{ Indicator } & \multicolumn{1}{|c|}{ Innovation Performance } & SHRM & Knowledge Management \\
\hline Innovation & Pearson Correlation & 1 & & \\
Performance & Sig. (2-tailed) & & & \\
& $\mathrm{N}$ & 58 & & \\
\hline SHRM & Pearson Correlation & $\mathbf{. 9 8 4 * *}$ & 1 & \\
& Sig. (2-tailed) & .000 & & \\
& $\mathrm{~N}$ & 58 & 58 & \\
\hline Knowledge & Pearson Correlation &. $\mathbf{9 7 7 * *}$ & $\mathbf{9 7 2 * *}$ & 1 \\
Management & Sig. (2-tailed) & .000 & .000 & \\
& $\mathrm{~N}$ & 58 & 58 & 58 \\
\hline
\end{tabular}

$\mathrm{n}=58$ (two-tailed test). Standardized coefficients are reported

**. Correlation is significant at the 0.01 level (2-tailed).

\subsection{Findings and Implications}

This study examined the variables as knowledge management, SHRM and innovation performance. The results indicate that strategic HR practices relate positively to innovation performance and knowledge management subsequently. These findings feature the important role of human resource management and knowledge management in the process of innovation. 
The determination of the correlation matrix reported the following:

- Strategic human resource management practices and innovation performance are positively correlated and this correlation is stable and statistically significant $(r=0.984, p=.000)$. Thus, the null hypothesis is rejected and H1 is accepted (The level of SHRM practices positively relates to innovation performance).

- Innovation performance and knowledge management are positively correlated and this correlation is stable and statistically significant $(\mathrm{r}=0.977, \mathrm{p}=.000)$. Accordingly, the results support $\mathrm{H} 2$ which is accepted (Innovation practices in a company positively relates to the knowledge management). The study results in Baron and Kenny's (1986) procedure to analyze the effect of knowledge management capacity between strategic HR practices and innovation performance.

- Knowledge management and strategic human resource management practices are positively correlated and this correlation is stable and statistically significant $(\mathrm{r}=0.972, \mathrm{p}=.000)$. Consequently, the null hypothesis is rejected and $\mathrm{H} 3$ is accepted.

Accordingly, the analysis outcomes indicate the positively correlated variables. Thus, one variable considers to be unsustainable without two other variables and conversely. Another words, to keep a balance, SHRM practices should be equalized both with innovation performance and knowledge management. The practical significance of the results is that HR supervisors demand vigorously to use the company's human capital by adapting different strategies in HRM to further trigger the role of knowledge management.

Respectively, the study connects the conceptual model and suggested hypotheses as a self-balance cycle' to indicate the importance of knowledge management and innovation performance in further SHRM practices. Another observation is empirically examined process of variable relationships among strategic HR practices, knowledge management and innovation performance. Where the knowledge management can positively vitalize creativity, design thinking and innovation approaches that ultimately advantage on company's innovative performance. To stimulate the SHRM practices and innovation performance, the HRM practitioners have to observe and perceive the essential importance of knowledge management with focusing on SHRM practices that eventually lead to effective and efficient innovative solutions.

\section{CONCLUSION}

The paper tried to reflect the role of SHRM through innovation and knowledge management. Correlation analysis of observed data proved significant and strong correlation. The study developed an empirical approach implications to further improve SHRM practices on business performance of tourism industry entities in Abu Dhabi. According to the proposed model, all criteria specified as knowledge management and innovation performance have a unique and particular positive effect on HRM practices.

Another part of the study is an essential and importantly increasing role of innovation performance and as a results its competitive advantage over other companies. Innovation as a result of inspiration and imagination strongly depends on company's human capital resources. Consequently, the superior and effective approach towards development of human capital, the more sophisticated results are expected for the innovation performance. Concluding, for better innovation performance of travel agent workers, a significant attention has to be paid to further improvement of SHRM practices. A special practice has to be implemented to increase the human capital development by utilizing training needs and most importantly the process of identifying the gap in employee training and related training needs.

\section{REFERENCES}

[1] Argote, L., McEvily, B., and Reagans, R. (2003). Introduction to the special issue on managing knowledge in organizations: Creating, Retaining, and Transferring knowledge. Management Science, 49(4): 5-8.

[2] Baron, R. M., and Kenny, D. A. (1986). The moderator-mediator variable distinction in social psychological research: Conceptual, strategic and statistical considerations. Journal of Personality and Social Psychology, 51(2): 1173-1182.

[3] Bantel, K. A., and Jackson, S. E. (1989). Top management and innovations in banking: Does the composition in top team make a difference. Strategic Management Journal, 10: 107-124. 
Innovation as a Source of Competitive Advantage in Human Resource Management: Case of Travel Agencies in the UAE

[4] Becker, B., and Gerhart, B. (1996). The impact of human resource management on organizational performance: Progress and prospects. Academy of Management Journal, 39(4): 779-801.

[5] Bontis, N. and Serenko, A. (2009). Longitudinal knowledge strategizing in a long-term healthcare organization. International Journal of Technology Management, 47(1-3): 276-297.

[6] Brockbank, W. (1999). If HR were really strategically proactive: Present and future directions in HR's contribution to competitive advantage. Human Resource Management, 38(4): 337-352.

[7] Chen Chung-Jen and Huang Jing-Wen (2009). Strategic human resource practices and innovation performance: the mediating role of knowledge management capacity, Journal of Business Research, 62(1): 104-114.

[8] Collins, C.J. and Smith, K.G. (2006) Knowledge exchange and combination: the role of human resource practices in the performance of high technology firms. Academy of Management Journal, 49: 544-560.

[9] Collins, C. J., and Clark, K. D. (2003). Strategic human resource practices, top management team social networks, and firm performance: The role of human resource in creating organizational competitive advantage. Academy of Management Journal, 46(6): 740-751.

[10] Crossan, M. M., andApaydin, M. (2010). A multi-dimensional framework of organizational innovation: A systematic review of the literature. Journal of Management Studies, 47(6): 1154-1191.

[11] Damanpour, F., and Evan, W. M. (1984). Organizational innovation and performance: The problem of organizational lag. Administrative Science Quarterly, 29: 392-409.

[12] Davila T; Marc J; Epstein and Shelton R., (2006). Making innovation work: how to manage it, measure it, and profit from it. Upper Saddle River: Wharton School Publishing.

[13] DCCI (2010). Dubai Chamber of Commerce and Industry, Information Centre, Dubai.

[14] EW (2010). Dubai Economic Forecast, viewed 10 March 2018, retrieved from http://www.economy watch.com /world_economy/dubai/economic-forecast.html.

[15] Furchtgott E and Furchtgott M. (1999). Aging and human motivation. New York: Kluwer Academic /Plenum Publishers.

[16] Gold, A.H., Malhotra, A., Segars, A.H., (2001). Knowledge management: An organizational capabilities perspective. Journal of Management Information Systems, 18(1): 185-214.

[17] Gomez-Mejia, L. R., Larraza-Kintana, M., Makri, M. (2003). The determinants of executive compensation in family-controlled public corporations. Academy of Management Journal, 46: 226-237.

[18] Guthrie, J. P. (2001). High-involvement work practices, turnover, and productivity: Evidence from New Zealand. Academy of Management Journal, 44(1): 180-190.

[19] Grant, Robert M. (1996). Toward a knowledge-based theory of the firm. Strategic Management Journal, 17: 109-122.

[20] Hamel, G (2008). Strategy and Innovation, World Innovation Forum, New York.

[21] Hansen, M. T. (1999). The search-transfer problem: The role of weak ties in sharing knowledge across organization subunits. Administrative Science Quarterly, 44: 82-111.

[22] Huselid, M. A. (1995). The impact of human resource management practices on turnover, productivity, and corporate financial performance. Academy of Management Journal, 38(3): 635-672.

[23] Jamrog, J., Vickers, M., and Bear, D. (2006). Building and sustaining a culture that supports innovation. Human Resource Planning, 29(3): 9-19.

[24] Jaw, B. S., and Liu, W. (2003). Promoting organizational learning and self-renewal in Taiwanese companies: The role of HRM. Human Resource Management, 42(3): 223-241.

[25] Jiang, K., Lepak, D., Han, K., Hong, Y., Kim, A. and Winkler, A.L. (2012). Clarifying the construct of human resource systems: relating human resource management to employee performance. Human Resource Management Review, 22(2): 73-85.

[26] Jiménez-Jiménez, D., and Sanz-Valle, R. (2011). Innovation, organizational learning, and performance. Journal of Business Research, 64(4): 408-417.

[27] Kvam, G.-T., and E. P. Strate. (2010). Innovation and diffusion: different roles in developing nature-based tourism. The Open Social Science Journal, 3: 30-40.

[28] Lawson, B. and Samson, D. (2001). Developing innovation capability in organizations: a dynamic capabilities approach. International Journal of Innovation Management, 5(3): 377-400.

[29] Lengnick-Hall, M.L., Lengnick-Hall, C.A., Andrade, L.S., Drake, B., (2009). Strategic human resource management: The evolution of the field. Human Resource Management Review, 19: 64-85.

[30] Leopold, J., Harris, L., (2009). The Strategic managing of human resources. (2th ed). Prentice Hall.

[31] Li Y, Zhao Y and Liu Y (2006). The relationship between HRM, technology innovation and performance in China, International Journal of Manpower, 27(7): 679-697. 
Innovation as a Source of Competitive Advantage in Human Resource Management: Case of Travel Agencies in the UAE

[32] Madanmohan, T (2003). A Framework for analysing innovative capability of firms in network industries. Working paper. Indian Institute of Management Bangalore. Bangalore.

[33] Madhavan, R., and Grover, R. (1998). From embedded knowledge to embodied knowledge: Newproduct development as knowledge management. Journal of Marketing, 62(4): 1-12.

[34] Mangion, M. L. and Vella, L. (2000). The Economic Impact of Tourism in Malta, Malta Tourism Authority, Valletta.

[35] Martinsons, M. G. (1995). Knowledge-based systems leverage human resource management expertise. International Journal of Manpower, 16(2): 17-34.

[36] Millmore, M., Lewis, P., Saunders, M., Thornhill, A., Morrow, T. (2007). Strategic human resource management: Contemporary issues. Harlow, England: Prentice Hall.

[37] Nonaka, I., and Takeuchi, H. (1995). The Knowledge-creating company. New York: Oxford University Press.

[38] Pfeffer, J., (1998). Seven practices of successful organizations. California Management Review, 40(2): 96-124.

[39] Pourkiani, M., Salajeghe, S., Ranjbar, M., (2011). Strategic human resource management and organizational knowledge creation capability. International Journal of e-Education, e-Business, eManagement and e-Learning, 1(5): 416-421.

[40] Urry, J. (2000). Sociology beyond societies. London: Routledge. Google Scholar.

[41] Ruggles, R. (1998). The state of the notion: knowledge management in practice. California Management Review, Vol. 40, No. 3, pp. 80-9.

[42] Sandybayev, A., Houjeir, R., Reczey, I. (2018). Exploring trends in tourism motivation, a case of tourists visiting the United Arab Emirates. Noble International Journal of Social Sciences Research, 3(1): 1-8.

[43] Scarbrough, H. (2003). Knowledge management, HRM and the innovation process, International Journal of Manpower, 24(5): 501-516.

[44] Snell, S. A. and Bohlander, G. W. (2012). Managing human resources. Mason: Cengage Learning. ISBN 13: 978-1-111-53282-6.

[45] Subramaniam, M. and Youndt, M.A. (2005). The Influence of intellectual capital on the types of innovative capabilities. Academy of Management Journal, 48(3): 450-463.

[46] Tidd, J., Bessant, J. R., and Pavitt, K. (2005). Managing innovation: Integrating technological, market and organizational change. Hoboken: Wiley.

[47] Trott, P., (2005). Innovation management and new product development. 4th ed., FT-Prentice Hall, UK.

[48] Skarzynski, P and Gibson, R. (2008). Innovation to the core. Boston: Harvard Business press.

[49] Von Krogh, G. (1998). Care in knowledge creation. California Management Review, 40: 133-154.

[50] Youndt M.A., Snell S.A., Dean J.W and Lepak D.P. (1996). Human resource management, manufacturing strategy, and performance. Academy of Management Journal, (39): 836-866.

[51] Wang, Z., Zang, Z., (2005). Strategic human resources, innovation and entrepreneurship Fit. International Journal of Manpower, 26(6): 544-606.

[52] WEF (2010). The Arab World Competitiveness Review 2010, World Economic Forum, Geneva.

[53] Wright, P.M., and McMahan, G.C. (1992). Theoretical perspectives for strategic human resource management. Journal of Management, 18(2): 295-320.

[54] Wright, P. M., andSnell, S. A. (1991). Toward an integrative view of strategic human resource management. Human Resource Management Review, 1(3): 203-225.

[55] TCA Abu Dhabi (2018).UAE-Department of Culture and Tourism, retrieved from: http://tcaabudhabi.a e/en/who.we.are/reports.statistics.aspx

Citation: Dr. Almaz Sandybayev (ADMC), Dr. Roudaina Houjeir (ADMC). "Innovation as a Source of Competitive Advantage in Human Resource Management: Case of Travel Agencies in the UAE ". International Journal of Research in Tourism and Hospitality (IJRTH), vol 4, no. 2, 2018, pp. 48-55. doi: http://dx.doi.org/10.20431/2455-0043.0402006.

Copyright: (c) 2018 Authors. This is an open-access article distributed under the terms of the Creative Commons Attribution License, which permits unrestricted use, distribution, and reproduction in any medium, provided the original author and source are credited. 